BARTŁOMIEJ RÓŻYCKI

Wydział Nauk Historycznych UMK

\title{
Kryzys amerykańskiego mesjanizmu. $O$ impasie w polityce zagranicznej USA po zakończeniu zimnej wojny
}

Nikt z wielkich tego świata nie potrafi w dającym się przewidzieć czasie rzucić śmiertelnego wyzwania Ameryce [...] Dlatego stulecie niedawno rozpoczęte też będzie „stuleciem Ameryki”, ale Ameryki coraz bardziej osłabionej i chorej, która nie potrafi zaprowadzić porządku i bezpieczeństwa ani na własnych ścieżkach, ani na szlakach świata, choć umie wysyłać rakiety na Marsa. Jeśli cokolwiek będzie w stanie zagrozić pozycji „samotnego supermocarstwa", to tylko ono samo*.

istoria Stanów Zjednoczonych stanowi coś w rodzaju globalnej, niespersonifikowanej wersji swojego własnego mitu - success story, od pucybuta do milionera, ale w wymiarze nie pojedynczej osoby, lecz kraju, jako członka międzynarodowej społeczności. Dwa i pół wieku dziejów USA to ciągła ewolucja, prowadząca od zjednoczenia się celem uzyskania niepodległości kilku- 
nastu kolonii, stanowiących zaledwie niewielki i wcale nie najważniejszy fragment Imperium Brytyjskiego, aż po mocarstwo o bezwzględnie największym potencjale militarnym i ekonomicznym na świecie. Droga pomiędzy tymi dwoma biegunami pełna jest rozmaitych stopni pośrednich - od pełnej determinacji walki o niezależność przez agresywne ubieganie się o rolę regionalnego lidera, zazdrosne strzeżenie swego stanu posiadania pod szyldem izolacjonizmu, wreszcie niechętnego skierowania swej uwagi na losy „starego świata" i nagłego przekroczenia tej niewyraźnej granicy pomiędzy ingerencją wojskową a narzuceniem własnej woli politycznej i modelu ustrojowego - jeszcze skromnie i jakby mimochodem po pierwszej wojnie światowej, z pełną natomiast świadomością i zdecydowaniem po drugiej. Zimnowojenna rywalizacja ze Związkiem Radzieckim o miano pierwszej siły na świecie to ostatnia scena tych zmagań. Nie dostosowała się ona jednak do filmowego standardu, gdzie w momencie kulminacyjnym dochodzi do ostatecznego starcia samych zainteresowanych, ani nie spełniła apokaliptycznych wizji nuklearnej zagłady, po której nie byłoby już żadnego zwycięzcy. Mimo tego „uszczerbku” z punktu widzenia scenarzystów wielkich hollywoodzkich produkcji, zakończenie zimnej wojny, rozpad Związku Radzieckiego, wyzwolenie państw bloku wschodniego (na zachodzie symbolizowane raczej przez upadek muru i zjednoczenie Niemiec niż przez Okrągły Stół), to moment zasadniczego happy endu owej epickiej, ponad dwustuletniej historii. Filmy w takim momencie mają zwyczaj się kończyć. Na początku lat dziewięćdziesiątych ubiegłego stulecia światu również zwiastowano rychłe szczęśliwe dopełnienie pisanego przez tysiąclecia scenariusza. Prorokowany przez Fukuyamę ${ }^{1}$ „koniec historii” miał być początkiem nowego ładu - zdominowanego przez liberalną demokrację i wolny rynek globalnego pokoju i współistnienia. Ostatnim zadaniem świata miało być jedynie rozciągnięcie tego „najlepszego z możliwych systemów” na pozostałe, najbardziej zacofane jego regiony.

Ani wcześniejsza wizja apokaliptyczna, ani bardziej aktualna idealistyczna nie spełniły się. Świat szybko przypomniał o swojej złożoności i nierozwiązywalności kluczowych problemów, a historia - że jedynie w świecie filmu kończy się ona na wybranym momencie, że w rzeczywistości miliarder równie dobrze może żyć aż do śmierci w dostatku, jak i w mgnieniu oka stracić swoją fortunę bądź zostać skazanym na dożywocie za oszustwa finansowe. Równie szybko okazało się, że i przed Stanami Zjednoczonymi stoją poważniejsze zadania, niż jedynie dyskontowanie dotychczasowych sukcesów. Efektem tych zjawisk było nieoczekiwane zakwestionowanie światowej roli

Zob. F. Fukuyama, Koniec historii, przeł. T. Bieroń, M. Wichrowski, Poznań 1996. 
USA. Perspektywa światłego przywództwa szybko okazała się mrzonką. Niewątpliwie, polityka zagraniczna tego supermocarstwa znalazła się w kryzysie, poprzez szereg błędnych działań doprowadzając do zachwiania własnej, zdawało się nienaruszalnej, potęgi.

W niniejszym artykule pragnę zastanowić się nad reinterpretacją roli Stanów Zjednoczonych w świecie, jaka dokonała się po zakończeniu zimnej wojny i wyjaśnieniu przyczyn kryzysu amerykańskiej polityki zagranicznej w ciągu ostatnich dwudziestu lat. Przywołując rozmaite analizy i przewidywania, chciałbym zaproponować własny sposób poszukiwania odpowiedzi na pytanie o obecny status największego światowego mocarstwa. Być może pozwoli ona również na mniej utopijno-idealistyczne, a bardziej analityczne spojrzenie na możliwe warianty jego przyszłości, a także umożliwi odpowiedź na pytanie o ewentualne przywrócenie światu amerykańskiego przywództwa, zgodnego z aspiracjami tego kraju.

\section{Pozycja Stanów Zjednoczonych po zakończeniu zimnej wojny}

Upadek systemu komunistycznego był przez Stany Zjednoczone uznany za wielki sukces własny. Nie wnikając, na ile był on rezultatem działań amerykańskiej administracji, a na ile wewnętrznych problemów ZSRR, po okresach wielo- i dwubiegunowości, nastać miał czas jednego supermocarstwa narzucającego światu swój porządek. Rola światowego przywódcy jako pierwszemu przypadła George'owi Bushowi. Jego program w istocie zakładał stworzenie świata unilateralnego, choć oczywiście nie tyle na zasadach rozwiązań siłowych, lecz poprzez swoistą aklamację ,jedynego słusznego" rozwiązania przez społeczność międzynarodową. W orędziu o stanie państwa z 1991 roku ogłaszał on powstanie „nowego ładu światowego”, epoki „wolnej od zagrożenia terroryzmem, sprawiedliwszej, z większą pewnością osiągania pokoju, w której narody świata, na Wschodzie, Zachodzie, Północy i Południu będą mogły rozwijać się oraz żyć w zgodzie i będą wspólnie odpowiedzialne za zachowanie wolności i sprawiedliwości na świecie. [...] Narody będą wspólnie dążyć do osiągnięcia uniwersalnych wartości ludzkości: pokoju i bezpieczeństwa, wolności i zasad prawa" . Rola USA jako przywódcy, integrującego i koordynującego działania dążących do pokoju rządów państw oraz instytucji, była niepodważalna: „patrząc w przyszłość bardzo wyraźnie widzę rolę, jaką Stany Zjednoczone powinny odgrywać w nowym wyłaniającym się świecie. [...] Jako czołowa demokracja i światło przewodnie wolności oraz kraj obdarzony wolnością, zasobami naturalnymi, a także korzystnym

Polityka zagraniczna USA po zimnej wojnie, red. J. Zając, Toruń 2005, s. 21. 
położeniem geograficznym, mamy nieporównanie większą odpowiedzialność za wykorzystanie posiadanej potęgi do osiągania wspólnego dobra. Ciąży na nas także obowiązek przewodzenia. [...] Jeżeli Stany Zjednoczone uchylą się od przewodzenia światu, nie będzie żadnego przywództwa [...]. Jeżeli nie zachcemy dźwigać ciążącej na nas odpowiedzialności, uchylimy się od ciążących na nas obowiązków i przyjmiemy wobec świata postawę obojętną, niewątpliwie pewnego dnia zapłacimy najwyższą cenę za nasze zaniechania i naszą krótkowzroczność" ${ }^{3}$. W formie konkluzji, przywództwo amerykańskie zostało w tym przemówieniu określone wprost jako indispensable ${ }^{4}$.

Pomimo tych górnolotnych zapowiedzi, stopień wypełnienia powyższych założeń przez kolejnych amerykańskich prezydentów określić można jako niewystarczający. Słabość i bezcelowość licznych inicjatyw władz Stanów Zjednoczonych stała się tematem rozważań wielu autorów ${ }^{5}$. Podstawowym czynnikiem, wpływającym na ten stan, było pojawienie się nowych problemów i wyzwań, które zmusiły do zaprzestania rozpamiętywania tych już rozwiązanych i ostatecznie pogrzebały tezę o „końcu historii”. Zaczęto zadawać pytania o sens dalszego funkcjonowania instytucji zimnowojennych, takich jak NATO ${ }^{6}$. Wreszcie Zachód, który wcześniej w strachu przed komunizmem zjednoczył się w cieniu Ameryki, przestał podążać jedną drogą, rozpoczęła się jego dezintegracja (choć oczywiście nie należy przeciwstawiać obecnej sytuacji rzekomej dawnej jedności - byłoby to mitologizowanie dziejów Europy Zachodniej, która nawet w okresie zimnej wojny nie była wolna od sporów wewnętrznych) ${ }^{7}$. Działania USA w nowej rzeczywistości często okazywały się nieskuteczne - zarówno jeśli chodzi o interwencje militarne, jak i działania dyplomatyczne - niepotrafiące ukrócić samodzielnej polityki prowadzonej przez liderów, takich jak Hugo Chávez czy Mahmud

\section{Tamże.}

Tamże.

Dla przykładu Jerzy Surdykowski pisał o Ameryce następująco: „Nie potrafi wymusić przestrzegania praw człowieka ani w małej Birmie, ani w wielkich Chinach. Drwią z niej Albańczycy polujący dziś na Serbów, drwili Serbowie niedawno polujący na Albańczyków. W podupadłej Somalii Amerykanie usiłowali rozdzielić bandy zwalczających się nawzajem rzezimieszków, ale wycofali się w niesławie, gdy tylko któryś z bandytów skutecznie podłożył bombę pod ich koszary. Na Kubie siedzi wciąż ten sam Fidel, nad Eufratem Saddam, na pustyni Kadafi. W Syrii wyrósł młody, jeszcze gorszy Assad, w Afganistanie upiorny Bin Laden. W Palestynie nowe, o wiele bardziej zajadłe $\mathrm{i}$ antyżydowskie pokolenie Intifady. Pakistan i Indie pokątnie zmajstrowały bomby atomowe i właśnie wygrażają sobie nimi jak skłóceni przekupnie kijami". J. Surdykowski, dz. cyt., s. 151.

T. Todorov, Nowy nieład światowy. Refleksje Europejczyka, przeł. E. Cylwik, Warszawa 2004, s. 93-94.

Zob. T. Kisielewski, Imperium Americanum? Międzynarodowe uwarunkowania sprawowania hegemonii, Warszawa 2004, s. 25-27. 
Ahmadineżad ${ }^{8}$. Złożoność współczesnego świata stała się zresztą wielkim problemem nie tylko dla polityków, ale i dla badaczy próbujących przewidzieć dalsze jego przemiany ${ }^{9}$.

Wyróżnić można dwie główne przyczyny kryzysu, w jakim znalazła się u schyłku dwudziestego stulecia dopiero co triumfująca Ameryka. Pierwszy z nich wiąże się z ograniczeniami czysto przestrzennymi, czy mówiąc wprost - geograficznymi. Na przestrzeni dziejów rozwój mocarstw warunkowany był zazwyczaj ekspansją terytorialną. W czasach współczesnych kwestia ta tak naprawdę nie uległa zmianie, choć oczywiście zmieniły się kryteria podporządkowania, które nie musi wcale oznaczać dominacji instytucjonalnej, lecz choćby skłonność do zawierania współpracy gospodarczej ${ }^{10}$. Jak zauważa Emmanuel Todd ${ }^{11}$, to światowa (a przynajmniej hemisferyczna) dominacja Stanów Zjednoczonych od lat pięćdziesiątych zainicjowała proces globalizacji - ujednolicania się kultur, systemów politycznych i gospodarek; innymi słowy okazywania swojej lojalności Ameryce poprzez upodabnianie się do niej w każdej sferze życia społeczno-politycznego. Popularna obserwacja, że państwa, w których funkcjonuje sieć McDonald's, nie toczą między sobą wojen $^{12}$ (zaprzeczył jej dopiero w 2008 roku konflikt rosyjsko-gruziński), jest najlepszym podsumowaniem tego procesu. W zglobalizowanym świecie poszczególne państwa uzależniają się od siebie nawzajem, tak więc i USA stały się po części zakładnikiem swoich bliższych i dalszych sojuszników. Todd zauważa, że Stany Zjednoczone, kraj o wielkiej sile, ale równie wielkich potrzebach, znalazł się w sytuacji zmuszającej go do ciągłego prowadzenia konfliktów. Bez nieustannych bojów, czy to militarnych, czy politycznych, obecnie niemożliwe byłoby nawet utrzymanie w USA aktualnego poziomu życia, o rozwoju i bogaceniu się nie wspominając. Z drugiej strony, wraz $\mathrm{z}$ upadkiem systemu komunistycznego drastycznie zmniejszyło się pole ma-

Zob. F. Fukuyama, Ameryka na rozdrożu: demokracja, władza i dziedzictwo neokonserwatyzmu, przeł. R. Staniecki, Poznań 2006, s. 161-171.

' W. Szymborski zabierając się za krytyczną analizę polityki prowadzonej przez George'a W. Busha napisał: „Świat po zakończeniu zimnej wojny stał się bez wątpienia bardziej dynamiczny i mobilny, aniżeli układy funkcjonujące w minionych stuleciach. Procesy polityczne, społeczne i gospodarcze zaczęły ulegać coraz szybszym przemianom, co notabene znacznie utrudnia ocenę rzeczywistości i czyni prognozowanie zadaniem trudnym i ryzykownym". W. Szymborski, Doktryna Busha, Bydgoszcz 2004, s. 19. Zob. E. Haliżak, Liberalna wizja porzadku międzynarodowego, [w:] Porzadek międzynarodowy u progu XXI wieku: wizje - koncepcje - paradygmaty, red. R. Kuźniar, Warszawa 2005, s. 66-68. E. Todd, Schyłek imperium: rozważania o rozkładzie systemu amerykańskiego, przeł. A. Szeptycki, K. Mączyńska, Warszawa 2003.

12 The Lexus and the Olive Tree. Thomas L. Friedman [http://www.thomaslfriedman.com/bookshelf/the-lexus-and-the-olive-tree; dostęp: 12.10.2009]. 
newru dla takiej polityki. Wrogiem Stanów Zjednoczonych nie jest już porównywalnie wielkie mocarstwo, ale szereg pomniejszych państw, nieakceptujących zasad globalnej gry narzuconej przez USA. Rządzone są one przez autorytarnych bądź quasi-demokratycznych przywódców korzystających z socjalistycznej i nacjonalistycznej ideologii. Ponieważ USA oprócz poszerzania wpływów potrzebują również uzasadnienia dla swojej pozycji światowego lidera (Zbigniew Brzeziński zwraca uwagę na fakt, że amerykańskie przywództwo nie zostało w żaden sposób formalnie legitymowane przez społeczność międzynarodową ${ }^{13}$ ), według Todda jednym z głównych założeń obecnej strategii politycznej jest nierozwiązywanie żadnego problemu do końca. Niezależnie od czysto wojskowych aspektów możliwości obalenia poszczególnych dyktatorów, istnienie wrogiego obozu uzasadnia dalszą amerykańską dominację nad pozostałą częścią świata i pozwala dalej uczestniczyć w niekończącym się wyścigu zbrojeń ${ }^{14}$.

Druga, według mnie nawet istotniejsza przyczyna amerykańskiego impasu, dotyczy w mniejszym stopniu kwestii ekonomicznych czy militarnych, lecz obejmuje ogólniejszy wymiar filozofii, zgodnie z którą państwo amerykańskie prowadzi swoją politykę. Łączy się ona z przywoływanym przez Todda „paradoksem Fukuyamy”. Wspominany już tu filozof wysnuł tezę, że triumf USA oznacza jednocześnie utratę przez ten kraj jego szczególnej roli i powoduje, że staje się on po prostu zbędny. Przy założeniu że „cały świat się demokratyzuje”, znika zapotrzebowanie na Wielkiego Brata czy światowego żandarma - wszak demokracje nie toczą między sobą wojen. Ameryka traci więc w ten sposób uzasadnienie swojego funkcjonowania uzasadnienie, które jest jej potrzebne nie tylko jako argument stosowany wobec innych, ale także jako swoisty kompas, którym państwo posługuje się, wyznaczając linię prowadzonej polityki ${ }^{15}$. Podobnie jak zaczęły być stawiane pytania o sens istnienia NATO, zimnowojennego przecież tworu, którego odpowiednikiem we wrogim obozie był Układ Warszawski, tak samo zaczęły narastać wątpliwości co do dalszej roli Ameryki i konieczności jej wpływania na losy świata, w stopniu tak dalece większym od jakiegokolwiek innego kraju. Jak zauważa Jerzy Surdykowski, „w świecie dwubiegunowym narody kochały Stany Zjednoczone jako niezawodną tarczę przeciw Sowietom, lecz w świecie jednobiegunowym stary oręż okazuje się zbędny, a jego dźwiganie - jakże męczące. [...] Stany Zjednoczone są postrzegane nie tyle jako imperialista dybiący na ich terytoria, ile jako arogant agresywnie narzucający swoje

\footnotetext{
Z. Brzeziński, Druga Szansa, Warszawa 2008, s. 30.

E. Todd, dz. cyt., s. $21-30$.

Zob. tamże s. 16-20.
} 
standardy, swoją kulturę, swoje prawo, beztrosko depczący cudzą godność, bez oglądania się na nikogo pojmujący własne interesy" ${ }^{\text {"16 }}$. Ten obraz nie jest jednak do końca prawdziwy - w równym stopniu co z pewności o swojej sile, wynika on z posiadania przez Amerykanów mesjanistycznego przeświadczenia o swojej szczególnej roli ${ }^{17}$. Cały wiek dwudziesty, od interwencji w oba krwawe europejskie, z czasem przenoszące się na inne części świata, konflikty, po wspieranie zachodniego bastionu liberalnej demokracji, stanowił argument dla faktycznego istnienia takiego przeznaczenia. W obecnym, wielobiegunowym świecie, Stany Zjednoczone starają się ową misję kontynuować. Postawa rozumiejących ten temat badaczy jest rozmaita - ograniczając się jedynie do tych już wspominanych - od napomnień, że „hegemon nie tylko musi mieć dobre zamiary, ale musi również rozważnie i mądrze wykorzystywać swą potęgę", po postulat „pokojowej abdykacji” - skorzystanie z obecnej sytuacji, by móc samemu ustalić warunki pozbawienia się mocarstwowej pozycji ${ }^{19}$. Naturalnie w samych Stanach Zjednoczonych opinie są najbardziej podzielone i nawet wielu krytyków polityki neokonserwatywnej domaga się utrzymania obecnej pozycji USA w świecie, jedynie na nieco zmienionych zasadach $^{20}$. Zdaniem Surdykowskiego to jednak świat bardziej potrzebuje Ameryki niż na odwrót - bez jej często niechętnie przyjmowanego wpływu zacznie ulegać dezintegracji. Z kolei samym Stanom Zjednoczonym powrót do izolacjonizmu mógłby się przysłużyć i pozwolić się wzmocnićc ${ }^{21}$.

${ }_{17}^{16}$ J. Surdykowski, dz. cyt., s. $145-146$.

Prostą lecz wiele wyjaśniającą diagnozę swojego własnego narodu przedstawił Robert Kagan: „Amerykanie są idealistami [...] Ale nie mają doświadczenia w skutecznym promowaniu swoich ideałów bez użycia siły [...] Amerykanie jako dobre dzieci Oświecenia nadal wierzą w możliwość poprawy człowieka i żywią nadzieję na poprawę świata [...] Amerykanie czasem nadal uważają, że odgrywają heroiczną rolę - że są jak Gary Cooper w samo południe. Będą chronić ludzi z miasteczka, bez względu na to, czy ci ludzie chcą tego czy nie". R. Kagan, Potęga i raj: Ameryka i Europa w nowym porzadku świata, przeł. W. Turopolski, Warszawa 2003, s. 110-111.

F. Fukuyama, Ameryka..., s. 171.

19 T. Kisielewski, dz. cyt., s. 131-134.

20 George Soros szkicuje własną wizję kontynuacji idei Pax Americana: „Musimy przewodzić wspólnym wysiłkom zmierzającym do poprawy światowego ładu, ponieważ tylko my możemy to zrobić. Jak dowodzą losy Międzynarodowego Trybunału Karnego, jak i Protokołu z Kioto [...] międzynarodowe porozumienia są znacznie mniej skuteczne, kiedy Stany Zjednoczone w nich nie uczestniczą. Biorąc pod uwagę naszą dominującą pozycję, to my zyskamy najwięcej sprawiając, że porządek świata będzie doskonalszy". G. Soros, Bańka amerykańskiej supremacji, przeł. D. Chylińska, Kraków 2004, s. 78.

${ }^{21}$ J. Surdykowski, dz. cyt., s. 146-147. 


\section{Hierarchia potrzeb jako schemat zmian w polityce zagranicznej}

Teza o mesjanistycznym charakterze amerykańskiej polityki zagranicznej zdecydowanie wyróżnia się pośród szeregu postulatów, często o charakterze kategorycznym, domagających się od Stanów Zjednoczonych zarzucenia polityki „imperialistycznej” i dominowania nad innymi krajami. Aleksander Lipatow pisał o postradzieckiej Rosji jako o „chorym Europejczyku”, „,niedojrzałym olbrzymie”, którego wewnętrzne wahania co do polityki, jaką powinien prowadzić (powrót do imperializmu czy westernizacja?) hamują jego działania i nie służą pozyskiwaniu sojuszników ${ }^{22}$. Wobec Stanów Zjednoczonych można by, poprzez analogię, ale i kontrast, wyciągnąć wniosek o podobnym charakterze - USA jest olbrzymem, który wcześniej wykorzystywał swoją potęgę, przekonany o wykonywaniu pewnej dziejowej misji. Teraz zagubił się w swych działaniach, bo niesieniu demokracji, chociażby „na bagnetach”, nie towarzyszy już idea - przez pół wieku legitymizowana istnieniem wyraźnego i równie silnego adwersarza. Nieprzypadkowo na początku tego artykułu zimnowojenne mocarstwa przyrównane zostały do bohaterów filmowych, chciałbym bowiem teraz zaprezentować diagnozę, której punktem wejścia jest potraktowanie Stanów Zjednoczonych tak, jakby mowa była o jednostce ludzkiej. Wiąże się to z zastosowaniem teorii wywodzącej się z nauki badającej właśnie zachowania pojedynczych ludzi, mianowicie psychologii. Modelem, na którym oparte będą poniższe rozważania, jest hierarchia potrzeb autorstwa Abrahama Maslowa.

Koncepcja ta jest stosunkowo prosta i popularna, chętnie adaptowana przez inne nauki i gałęzie wiedzy, takie jak choćby zarządzanie. Jej zasadniczym elementem jest przekonanie, że celem ludzkich działań zawsze jest dążenie do zaspokojenia określonych potrzeb. Człowiek nie jest w stanie osiągnąć pełnego zaspokojenia w dłuższym czasie. Zaspokojenie jednej potrzeby sprawia, że na jej miejscu pojawia się inna. Układają się one w swoisty ciąg przyczynowo-skutkowy, gdzie zaistnienie jednej warunkowane jest zaspokojeniem drugiej, ta zaś pojawiła się wskutek spełnienia jeszcze innej itd. Sekwencja ta obrazowana jest zazwyczaj za pomocą piramidy, u której podstaw leżą potrzeby najbardziej pierwotne, łączące człowieka ze zwierzętami, na samym szczycie zaś znajdują się te związane z intelektem i duchowością, pojawiające się zazwyczaj jedynie u osób o wysokim poziomie wykształcenia, inteligencji i kulturacji. Maslow podzielił potrzeby ludzkie na siedem kategorii: fizjologiczne, bezpieczeństwa, przynależności i miłości, szacunku, samo-

Zob. A. Lipatow, Rosja i Polska: konfrontacja i grawitacja, Toruń 2003, s. 388-389. 
realizacji, wiedzy i rozumienia oraz estetyczne. System z nich zbudowany działa w taki sposób, że spełnienie jednej potrzeby powoduje „uruchomienie" kolejnej - osłabiony z głodu człowiek nie będzie myślał o gromadzeniu zapasów pożywienia, dopóki się nie nasyci, zdesperowany bezrobotny poszukujący jakiejkolwiek pracy nie będzie się zastanawiał, czy dana propozycja zapewni mu w przyszłości wysoką emeryturę etc. Pierwsze pięć z wymienionych potrzeb cechuje się pewną właściwością, mianowicie znikają one wraz ze swoim zaspokojeniem. Nazywane są one potrzebami podstawowymi w przeciwieństwie do ostatnich dwóch - potrzeb wyższego rzędu - których zaspokajanie nie sprawia, że znikają, lecz przeciwnie - powoduje ich dalsze pogłębianie. Oznacza to więc, że człowiek zawsze odczuwa konieczność spełniania pewnych potrzeb i nigdy nie zaspokaja wszystkich ich w całości - nie ma zatem możliwości ziszczenia wszystkich swoich marzeń. Może wspinać się po poszczególnych szczeblach hierarchii, lecz nigdy nie osiągnie szczytu. Oczywiście w pewnych okolicznościach może też nastąpić regres i powrót do odczuwania konieczności zaspokojenia potrzeby niższego rzędu ${ }^{23}$.

Chciałbym w tym miejscu przedstawić własną propozycję, aby opisaną powyżej teorię spróbować poprzez analogię zastosować podczas próby wyjaśnienia zmian zachodzących $\mathrm{w}$ stosunkach międzynarodowych. Jednostki ludzkie w takim modelu zastępowane byłyby przez państwa, relacje przyjaźni i wrogości przez sojusze i konflikty, zaś zachowania przez działania rządów obejmujące nawiązywanie i zrywanie stosunków dyplomatycznych, udzielanie pomocy bądź nakładanie sankcji, czy też zawiązywanie współpracy lub prowadzenie wojen. Najbardziej skomplikowanym elementem modelu byłoby zagadnienie motywacji, jakimi kierują się w swych działaniach władze państw ${ }^{24} . Z$ pewnością wpływ na nie miałoby wiele czynników, takich jak choćby ustrój (inny zakres zaspokajania oczekiwań społecznych w demokracjach, niż w systemach autorytarnych, wpływ działania niezależnych mediów itp.). Tutaj chciałbym sprowadzić cele państwa do spełniania potrzeb

23 Oczywiście, jak każda teoria w naukach społecznych, również i ta musi zakładać pewne odstępstwa od sztywnego modelu. Maslow przyjmuje, że u pewnych ludzi może występować zaburzenie przedstawionej tu hierarchii, związane z uprzywilejowaniem pewnych potrzeb (np. przełożenie więzi rodzinnych i przyjacielskich ponad karierę zawodową). Co ciekawe natomiast, zgodnie z obserwacjami autora tego modelu wcale nie jest on związany jedynie ze specyfiką zachodniego stylu życia, lecz sprawdza się w każdym kręgu kulturowym. A. Maslow, Motywacja i osobowość, przeł. J. Radzicki, Warszawa 2006, s. 62-83.

Dla uproszczenia za jedynych uczestników tego modelu uznaję państwa, nie analizuję tu chociażby organizacji międzynarodowych, choć oczywiście i one mogłyby być uwzględnione na wyższym poziomie interpretacji. Z kolei za działania (zachowania) państwa uznaję świadomą i celową aktywność jego władz centralnych. Aspekty takie jak samodzielna polityka części składowych federacji czy wpływ ruchów społecznych uznaję nie za odrębne działania, ale za zmienne wywierające wpływ na działania samych władz. 
ujętych w hierarchii Maslowa. Oczywiście, również wobec nich przeprowadzić należy stosowną analogię. Odpowiednikiem potrzeb „fizjologicznych" w przypadku państwa może być konieczność ustanowienia jego najbardziej fundamentalnych składników, którymi według klasycznej definicji Jellinka są terytorium, ludność oraz władza. W istocie, wytyczenie granic terytorialnych, obejmujących określoną ludność, ustanowienie pewnej władzy zwierzchniej nad tym terytorium, a współcześnie również rozstrzygnięcie podstawowej kwestii obywatelstwa zamieszkującej ją ludności wydają się warunkami sine qua non istnienia państwa, bez których trudno mówić o nim jako o podmiocie stosunków międzynarodowych. Tak przynajmniej ogólnie określone państwo posiada już cechy umożliwiające mu bycie podmiotem na arenie międzynarodowej, choćby przez sam fakt, że inne państwa czy organizacje mogą się wobec jego powstania ustosunkować. Określenie przez państwo własnego terytorium skutkuje koniecznością uzgodnienia relacji z sąsiadami, szczególnie z tymi, którzy z racji swego położenia lub historii także mogą zgłaszać do danego terytorium pretensje. Natomiast brak organów władzy uniemożliwiałby nawiązywanie kontaktów z innymi państwami, gdyż brakowałoby podmiotu, który mogłyby one jednoznacznie uznać za przedstawiciela owego państwa.

W hierarchii Maslowa kolejną potrzebę stanowi bezpieczeństwo i tu również odnaleźć można daleko idące podobieństwo. W wypadku nowo powstałego państwa jego głównym zagrożeniem jest efemeryczność, zniknięcie $\mathrm{z}$ areny międzynarodowej w wyniku problemów wewnętrznych lub też agresywnych działań ze strony wrogów zewnętrznych (na przykład krajów wcześniej władających danym terytorium). Potrzebą, której zaspokojenie jest niezbędne, staje się więc konieczność zaprowadzenia ładu wewnętrznego, oraz zapewnienie sobie względnego bezpieczeństwa od zagrożeń zewnętrznych. Likwidacja problemów wewnętrznych może być związana z konfrontacją alternatywnych ośrodków władzy oraz likwidacją wewnętrznej opozycji ${ }^{25}$, zaś najważniejsze wyzwanie $\mathrm{w}$ stosunkach zewnętrznych stanowi obrona przez państwo własnej niepodległości i korzystne rozstrzygnięcie ewentualnych sporów terytorialnych. Państwo - funkcjonujące jako względnie trwały byt może stać się podmiotem bardziej zaawansowanych stosunków z innymi, zawierając sojusze, umowy o współpracy, wchodząc w skład organizacji mię-

25 Oczywiście nie musi się to kojarzyć z krwawą, bezwzględną rozprawą ze wszystkimi przeciwnikami politycznymi - zwłaszcza współcześnie zagadnienie to wiązałoby się raczej z pozbawieniem wpływów jedynie tych ruchów politycznych, które kwestionowałyby zasadność istnienia państwa czy też formułowałyby żądania separatystyczne, bądź też tych, które nie akceptowałyby reguł ustrojowych, jak choćby zasady demokratycznej walki o władzę. 
dzynarodowych. U Maslowa dążenie to nazywane jest potrzebą przynależności - jeśli mowa o samym aktywnym włączeniu się do społeczności międzynarodowej oraz szacunku - gdy dane państwo coraz bardziej zaznacza w nim swoją rolę i zyskuje przewagę nad innymi. I rzeczywiście, ratyfikowanie międzynarodowej konwencji podnosi pozycję państwa w oczach innych, czyniąc go wiarygodnym i przewidywalnym partnerem. Obecnie jest to szczególnie ważne w wypadku problemów, na które społeczność międzynarodowa jest szczególnie wrażliwa, jak prawa człowieka czy kwestia ochrony środowiska ${ }^{26}$. O ile potrzeby przynależności wiążą się z podkreślaniem faktu wyznawania tych samych zasad, co inni członkowie danej grupy, to potrzeby szacunku polegają raczej na wyróżnianiu się spośród nich. Niekoniecznie wyróżnienie to musi wiązać się z dodatkowymi korzyściami, poza samym prestiżem. Potrzeby związane z szacunkiem przekładać się mogą na działania dające państwu wymierne skutki (jak przejęcie kontroli nad bogatymi w surowce obszarami lub wiodąca rola w organizacji międzynarodowej), lub też na nieposiadające jakiegokolwiek znaczenia, poza właśnie prestiżowym (przykładem może być tu dziewiętnastowieczny wyścig o kolonie, nierzadko bezwartościowe pod względem strategicznym).

W wypadku kolejnych potrzeb wynikających z hierarchii Maslowa trudniej jest przeprowadzić tak bezpośrednie analogie. Potrzeby paralelne dla samorealizacji, rozumienia czy estetyki nie są już tak łatwo definiowalne. Tym niemniej w wypadku państw, które osiągnęły dany poziom rozwoju można zauważyć charakterystyczną dla potrzeb wyższego rzędu cechę, polegającą na dążeniu nie do ostatecznego zaspokojenia danej potrzeby, lecz do jej ciągłego zaspokajania. Państwo pewne swojej pozycji, funkcjonujące już przez pewien czas, niezagrożone przez czynniki zewnętrzne ani wewnętrzne, koncentruje się na realizacji ostatecznego celu, jakim jest walka o jak najlepszą pozycję na arenie międzynarodowej. Ze względu na faktyczny brak granicy odgórnej (musiałoby nią być całkowite podporządkowanie sobie świata, bez żadnych wyjątków), można uznać ją za przynależną tylko wybranym państwom potrzebę „wyższego rzędu”. W kolejnej części artykułu przyjrzymy się, jak Stany Zjednoczone przechodziły drogę przez kolejne szczeble hierarchii, od realizacji potrzeb najbardziej podstawowych aż po te najwyższe.

26 Jest to tak zwany active internationalism, będąca efektem dominacji USA doktryna, uznająca pewne prawa za naturalne i przynależne wszystkim narodom. E. Haliżak, Zmiana układu sil USA-Chiny a transformacja porządku międzynarodowego, Warszawa 2005, s. 112. 


\section{Rozwój i kryzys polityki zagranicznej Stanów Zjednoczonych}

Szukając egzemplifikacji dla powyższego modelu, historia Stanów Zjednoczonych wydaje się najlepiej go obrazować. Kraj ten w ciągu zaledwie kilku wieków swego istnienia przeszedł przez wszystkie szczeble proponowanej tu hierarchii. Wyartykułowaniem potrzeby samego istnienia państwa było rozpoczęcie w drugiej połowie XVIII wieku walki o niezależność od Wielkiej Brytanii. Deklaracja niepodległości i jej obrona w wojnie z metropolią, a także uchwalenie konstytucji stanowiły kroki, które doprowadziły do umocnienia Stanów Zjednoczonych jako suwerennego bytu państwowego. Od zakończenia wojny z Anglią w 1814 roku niepodległość USA nigdy nie była już zagrożona ${ }^{27}$. W kolejnych dekadach kraj ten wzmacniał się i rozszerzał swoje terytoria, można by rzec - zaspokajał potrzebę bezpieczeństwa poprzez umacnianie swojej pozycji. Dużo bardziej problematyczne niż w stosunkach międzynarodowych okazało się to zresztą w sprawach krajowych - choć konstytucja położyła kres dyskusjom ustrojowym, tak naprawdę dopiero zakończenie wojny secesyjnej doprowadziło do ostatecznej konsolidacji wewnętrznej. Nim to nastąpiło, Stany Zjednoczone na arenie międzynarodowej już prowadziły politykę określającą „przynależność” tego kraju. Pierwszym znaczącym krokiem było tu ogłoszenie w 1823 roku doktryny Monroe'a, która jasno określiła aspiracje USA do bycia wiodącą siłą na kontynencie amerykańskim i izolowania tego regionu świata od wpływów europejskich. Wiązało się to oczywiście z koniecznością uregulowania relacji z innymi krajami na kontynencie, a w szczególności z tymi, które ze Stanami Zjednoczonymi sąsiadowały. Granica z Kanadą pomimo komplikacji ostatecznie została ustalona pokojowo, choć przez cały XIX wiek stosunki pomiędzy obydwoma krajami przybierały także ostrzejsze formy, włącznie $\mathrm{z}$ dążeniami aneksjonistycznymi ze strony $\mathrm{USA}^{28}$. Z kolei spór graniczny z Meksykiem Stany Zjednoczone rozstrzygnęły zbrojnie, a postanowienia pokoju z 1848 roku nie pozostawiły złudzeń, które z państw dominuje we wzajemnych stosunkach.

Poszukując analogii dla kolejnych potrzeb - prestiżu i samorealizacji, należy pamiętać o uwadze Maslowa, że ich realizacja może być wieloetapowa i znacznie rozciągnięta $\mathrm{w}$ czasie, oraz że w zasadzie nigdy nie może być

27 Nieopatrzone przypisami dane na temat historii Stanów Zjednoczonych zaczerpnięte z: $\mathrm{Hi}$ storia Stanów Zjednoczonych Ameryki, t. 2, red. B. Sheehan, I. Wawrzyczek, Warszawa 1995 oraz W. Dobrzycki, Historia stosunków międzynarodowych 1815-1945, Warszawa 2003.

${ }^{28}$ W. Dobrzycki, Ewolucja stosunków kanadyjsko-amerykańskich, „Stosunki Międzynarodowe" 2000, nr 3-4, s. 92. 
w pełni zaspokojona. Historia Stanów Zjednoczonych od drugiej połowy XIX wieku aż po schyłek minionego stulecia wydaje się być najlepszym w dziejach świata przykładem rozwoju tej potrzeby i ciągłego dążenia do jej zaspokajania. Przykładem amerykańskich działań, świadczących o wzroście ambicji USA może być dalsze poszerzanie swych wpływów na kontynencie amerykańskim (kupno Alaski, polityka imperialna wobec państw Ameryki Łacińskiej, sprzeciw wobec europejskiej interwencji w Meksyku, przejęcie kontroli nad budową Kanału Panamskiego), a także rozprzestrzenienie swej działalności na inne rejony świata, jak udział w uzależnianiu Chin i Japonii od wielkich mocarstw kolonialnych. Wraz z rozszerzaniem swojej strefy wpływów, w amerykańskiej świadomości rozwinęły się aspiracje do zostania mocarstwem. Bardzo poważnym krokiem na drodze do urzeczywistnienia tych marzeń było wcielenie w życie teorii nawalizmu admirała Mahana, mającej zapewnić USA dominację na morzu. Podstawowymi elementami jej realizacji było odebranie Hiszpanii licznych posiadłości wyspiarskich na Atlantyku i Pacyfiku oraz przejęcie Hawajów ${ }^{29}$.

Wiek XX wprowadził Stany Zjednoczone na drogę dalszego rozwoju i uzyskiwania coraz większego wpływu na losy całego świata. Najbardziej doniosłymi i symbolicznymi tego przykładami były dwie wojny światowe, w których początkowej fazie USA nie przynależały do żadnego z sojuszy wojskowych i nie były przez to zobowiązane do zbrojnego zaangażowania się. Ich późniejsze włączenie się do konfliktu przeważyło jednak szalę zwycięstwa na jedną ze stron. Szczególnie uwidoczniło się to w działaniach prowadzonych przez Amerykanów podczas oraz po zakończeniu II wojny światowej. Lend-Lease Act, Karta Atlantycka, szereg konferencji międzynarodowych od Casablanki po Poczdam czy plan Marshalla to najbardziej podstawowy katalog wydarzeń mających olbrzymi wpływ na dalsze losy świata, a wszystkie one $\mathrm{w}$ całości lub znacznej części inspirowane i realizowane były właśnie przez Stany Zjednoczone ${ }^{30}$. Bez wątpienia możemy w tym momencie mówić już o wchodzeniu USA w rolę lidera światowego. Kraj ten nie był jednak liderem jedynym, po drugiej wojnie światowej na państwo o podobnej sile i aspiracjach wyrósł bowiem Związek Radziecki. Wydaje się, że powstałe wówczas potrzeby tych krajów, jak zdobycie politycznej, ekonomicznej i kulturowej dominacji nad resztą świata, nie mogły być zaspokojone przez obydwa jednocześnie. Rezultatem tego było wytworzenie systemu bipolarnego, w którym oba kraje objęły w posiadanie swoją strefę wpływów, jednocześnie rywa-

${ }^{29}$ G. B. Tindall, D. E. Shi, Historia Stanów Zjednoczonych, przeł. A. Bartkowicz, H. Jankowska, J. Ruszkowski, Poznań 2002, s. 871-872.

K. Michałek, Amerykańskie stulecie: historia Stanów Zjednoczonych Ameryki 1900-2001, Warszawa 2004, s. 221-228. 
lizując ze sobą. Mimo że nigdy nie doszło do bezpośredniej konfrontacji między nimi, walka prowadzona była głównie poprzez propagandę oraz działania dyplomacji i wywiadu, a „zastępcze" konflikty zbrojne toczone były w państwach Trzeciego Świata, oba mocarstwa zorientowane były na wzajemne zniszczenie. Fakt, że do tego nie doszło, wiąże się raczej z rozwojem nauki i techniki, zwłaszcza badaniami nad strategiczną bronią atomową, który sprawil, że dotychczasowe metody rozwiązywania konfliktów odeszły do historii. Niemniej określenie, że między Stanami Zjednoczonymi a Związkiem Radzieckim przez ponad 40 lat toczyła się swoista wojna jest jak najbardziej uzasadnione, podobnie jak i stwierdzenie, że wojna ta zakończyła się klęską ZSRR oraz wielkim zwycięstwem USA. Poprzez tę rywalizację Stany Zjednoczone uzyskały rolę jedynego światowego supermocarstwa i możliwość zaspokojenia, wymienionej już, potrzeby dominacji nad resztą globu. Dotychczasowy najpoważniejszy rywal popadł w kryzys tak głęboki, że jego przywódcy sami zdecydowali się na likwidację dotychczasowej formy ustrojowej, a utworzona na jego gruzach Federacja Rosyjska zmuszona była zbliżyć się do niedawnego śmiertelnego wroga i przyjąć wobec niego bardziej ustępliwe - choć oczywiście nie poddańcze - stanowisko ${ }^{31}$.

Problemy, na jakie natrafiła triumfująca Ameryka, zostały wskazane na początku artykułu. Pozostaje pytanie o przejście Stanów Zjednoczonych na kolejny szczebel w drabinie potrzeb. Katalog został niewielki - wiedza, estetyka, czasem dodawana jest jeszcze transcendencja. Również patrząc na amerykańską politykę od początku lat dziewięćdziesiątych, trudno odnaleźć wyraźny jej paradygmat. Problemy ostatnich dwóch dekad nie są dla Stanów Zjednoczonych dowodem ich „awansu". Obszary najpoważniejszych konfliktów, bo zakładających możliwość wykorzystania broni atomowej, jak problem Korei Północnej czy ostatnio Iranu, nie mogą być porównywane z najbardziej kryzysowymi momentami zmagań ze Związkiem Radzieckim. Mimo upadku bloku komunistycznego, jego położony najbliżej USA bastion - Kuba, do dziś nie zmienił charakteru ustrojowego. Oprócz niego także liderzy innych średniego znaczenia państw - na czele z Hugo Chávezem - prowadzą swoją politykę $\mathrm{w}$ oparciu o antyamerykańską retorykę. W przeciwieństwie do okresu zimnej wojny nie robią tego jednak mając za sobą wsparcie potężnego, euroazjatyckiego mocarstwa - ich własna siła okazuje się wystarczająca do bezkarnego prowadzenia politycznej rozgrywki ze Stanami Zjednoczonymi. Również wojna z terroryzmem, na chwilę obecną będąca głównym

${ }^{31}$ M. Kaczmarski, Ewolucja stosunków Federacji Rosyjskiej ze Stanami Zjednoczonymi Ameryki na początku XXI wieku, „Stosunki Międzynarodowe” 2005, nr 1-2, s. 39. 
problemem definiującym realia polityki międzynarodowej w XXI wieku, wykazała raczej słabość Ameryki. Podobnie jak obecny kryzys ekonomiczny, odsłaniający patologie stworzonego w głównej mierze przez USA światowego ładu gospodarczego.

\section{Perspektywy nowych wyzwań dla Ameryki}

Widzimy więc, że moment, w którym zaczyna brakować odniesienia pomiędzy zaprezentowaną teorią a praktyką, jest zarazem momentem kryzysu amerykańskiej dominacji - utraty przez Stany Zjednoczone kontroli nad wyznaczaniem sobie nowych celów oraz posiadanej przez większą część $\mathrm{XX}$ wieku inicjatywy w budowaniu ładu światowego. Tu moim zdaniem tkwi zasadnicza odpowiedź na pytanie o błędne koło, w jakim znajduje się amerykańska polityka zagraniczna - wraz z upadkiem systemu komunistycznego i pozostaniu na pobojowisku zimnej wojny jako jedyne supermocarstwo, Stany Zjednoczone wypełniły ostatni z wytyczonych sobie celów. Z powodu braku dalszych „wielkich” wyzwań nastąpił regres. Konieczność skupienia się jedynie na „doraźnych” problemach, jak atak Iraku na Kuwejt, kolejna wojna na Bałkanach, atomowe ambicje niektórych krajów czy wreszcie islamski terroryzm i kryzys ekonomiczny, pozbawiła Amerykanów poczucia misji, do której pełnienia zawsze się poczuwali. Jak zauważa Surdykowski, „Ameryka zawsze rozwijała się przez wyzwania, na które - nieraz z ogromnym wysiłkiem, ale skutecznie - potrafiła znaleźć odpowiedź,"32. Zgodnie zaś z paradoksem Fukuyamy - dając światu wolność, USA pozbawiły się prawa do decydowania o jego losie - ich nowi i dawni sojusznicy, czy może raczej podopieczni, mogli pójść własną drogą. Dla Ameryki skończył się czas wyzwań, zabrakło „potrzeb”, na których spełnianiu mogłaby się skupić. Paradygmaty polityki zagranicznej skupiły się na celach pragmatycznych: utrzymywaniu status quo i stałym potwierdzaniu własnej dominacji. Do tak nagłego spadku poziomu aspiracji nie mogło się przystosować ani amerykańskie społeczeństwo, ani kierujący polityką USA. Dyplomacja supermocarstwa znalazła się w kryzysie na długo, zanim pojawił się on na Wall Street.

$\mathrm{Na}$ koniec można zadać pytanie o perspektywy wyrwania się z tego zaklętego kręgu, innymi słowy - wyznaczenia Stanom Zjednoczonym nowych dróg rozwoju. $Z$ jednej strony stwarza to wprawdzie niebezpieczeństwo zboczenia na „manowce” futurologii, z drugiej zaś to brak odważnych projekcji przyszłości na początku ubiegłego stulecia doprowadził do wielkich tragedii. Jedną z łatwiejszych do wyantycypowania dróg rozwoju jest powrót do zmagań wielkich mocarstw. Obecna ekspansja Chin, nie tylko w Azji, ale

J. Surdykowski, dz. cyt., s. 165. 
również na kontynentach afrykańskim i południowoamerykańskim, głównie poprzez współpracę gospodarczą opartą na deklaracji rozumienia wzajemnych potrzeb, pozwala zakładać możliwość powstania nowego bipolarnego ładu światowego ${ }^{33}$. Oczywiście wizja ta jest trudna do skonkretyzowania, wielką niewiadomą pozostaje przede wszystkim rola w tym porządku Rosji, a także zjednoczonej Europy. Możliwe są też inne spekulacje. Już Aleksander Macedoński miał zapłakać, gdy zdobył cały świat i nie zostało mu nic do podbicia. Stany Zjednoczone natrafiły na dużo bardziej kategoryczne bariery poza drobnymi skrawkami świata, których podporządkowywanie, jak wspomniałem, wcale nie świadczy o rozwoju, amerykański styl, jeśli nie w polityce, to w gospodarce i kulturze, zadomowił się na całym globie. Być może USA trafiły na ograniczenia związane $\mathrm{z}$ aktualnym poziomem nauki, a przełomowe odkrycia na tym polu pozwoliłyby na ponowne wyznaczenie światu nowej drogi. Myślę tu o wznowieniu prób eksploracji kosmosu. o kierunku, który już dawno zafascynował ludzkość, który był w poprzednich dekadach obiektem mocarstwowej rywalizacji, a który przy okazji pozwoliłby wyrwać się z fizycznych ograniczeń dotychczasowego świata. Choć ten przykład to czysta spekulacja, prawdopodobnie tego formatu wyzwania potrzebują Stany Zjednoczone, by móc ponownie stać się dla świata liderem, a nie imperialistą. Natomiast gdyby prognoza ta okazała się trafna, można by z całą pewnością powiedzieć, że Ameryka odnalazła swoje miejsce w hierarchii potrzeb i aspiruje, w przenośni i dosłownie, do spełniania tych „najwyższego”, możliwego do wyobrażenia, rzędu.

33 E. Haliżak, Chiny-Afryka: instrumenty oddziaływania, niepublikowany materiał konferencyjny, I Ogólnopolski Kongres Politologii, Uniwersytet Warszawski, Warszawa, 23 września 2009. M. Wiktorowski, Wspótpraca gospodarcza ChRL z krajami Afryki w okresie 2000-2006, na bazie analizy informacji wtórnych, [w:] „Powrót smoka”. Marsz ku globalnej pozycji mocarstwa, red. J. Marszałek-Kawa, Toruń 2008, s. 69-84, J. Rowiński, Chiny-Ameryka Eacińska: szanse i wyzwania na progu XXI w., [w:] Ameryka Eacińska w regionie Azji i Pacyfiku, red. M. Gawrycki, Toruń 2007, s. $99-117$. 


\section{Abstract}

After the end of Cold War and the fall of USSR, the United States were fairly considered the mightiest country in the world. Not only their biggest rival for global domination has collapsed, but also American influence in politics, economy and culture spread around the world, including many former communist countries. American leadership seemed to be unquestionable. However, in the following years United States' foreign policy encountered grave obstacles which put in doubt their capability of global domination. However, those obstacles, including national and religious conflicts as well as anti-American regimes in different regions of the world, were nowhere close to threats and difficulties from the age of rivalry with USSR. Nonetheless, the United States are currently struggling with many of those problems, being unable to solve them and receiving growing criticism of their actions even from their traditional allies.

This paper focuses on a verification of the hypothesis that American global domination is lost or at least endangered. After a presentation of selected theories concerning this question, the author attempts to give a general explanation of American foreign policy current crisis. It is based upon an assumption of eternal American conviction of being a nation designated for a special mission of spreading their ideas all over the world. This attitude, which can be named messianism, is a core of this hypothesis, indicating lack of new strategic, non-particular objectives as the main reason of deadlock in this policy. To support the theory mentioned above, the author presents his own proposal to arrange, for the purpose of this analysis, a model that is well-known in psychology and sociology. Abraham Maslow's hierarchy of needs, originally used for explanation of human behavior, is now being used to analyse international politics, giving the states their own "motivations" for their actions, which depend on their position and level of development. Evolution of human needs is compared to the growing status of a country developing from its very beginning to the position of world leader, giving the history of USA as an example.

To recapitulate, basing on the conclusions of previously mentioned theory, the author attempts to indicate the factors that may allow the United States to regain their global dominance or, if this loss is inevitable and irreversible, finding their appropriate position in new world order. 